\title{
Anti-racist Text and Talk: A Critical Discourse Studies Approach to Black Feminism
}

\author{
Philip P. Limerick \\ Centre College, Danville, KY. USA \\ philip.limerick@centre.edu
}

\section{ARTICLE HISTORY \\ Received : 2021-05-17 \\ Revised : 2021-08-07 \\ Accepted : 2021-08-19}

\section{KEYWORDS}

Critical Discourse Studies Black Feminism

Anti-racism

Discourse analysis

Pragmatics

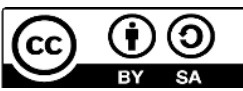

\begin{abstract}
While racist discourse has received much attention in Critical Discourse Studies (CDS), there is a dearth of scholarship on the anti-racist text and talk. A critical observation is that the anti-racist movement, and hence, discourse, often exclude women. With the goal of contributing to this gap in the CDS literature, the current analysis examines Black women's discourses concerning anti-Black racism in general and Black Feminism in particular. Four YouTube videos that feature both conference talks and news programs surrounding the topic of Black Feminism are analysed for recurring themes using thematic analysis and discourse structures from the perspective of critical discourse analysis. Findings reveal that the primary themes that emerged are the inclusion of Black women, Police brutality and unaccountability, and Black Feminism Defined, with various subthemes. In addition, the discourse structures examined are lexical choice, presupposition, pronominal choice, and the use of tag questions, among others. This study serves to further our understanding of the linguistic manifestation of ideologies through discourse concerning anti-racism and Black Feminism.
\end{abstract}

\section{Introduction}

While racist discourse has received much attention in Critical Discourse Studies, there is a dearth of scholarship on anti-racist text and talk (Van Dijk 2020). Anti-racist movements, and hence, discourse, often exclude women (Cooper, 2018). With the goal of contributing to this gap in the CDS literature, the current analysis examines Black women's discourses concerning anti-Black racism in general and Black Feminism in particular. ${ }^{1}$ The framework of Critical Discourse Analysis (CDA) aims to analyse "structural relationships of dominance, discrimination, power and control as manifested in language" and to "investigate critically social inequality as it is expressed, constituted, legitimised, and so on, by language use (or in discourse)" (Wodak and Meyer, 2009, 10). The data employed for this study come from four YouTube videos that feature both conference talks and news programs surrounding the topic of Black Feminism. This paper will first provide the necessary

1 I acknowledge my positionality as a white man in addressing issues of Black Feminism. Particularly, I understand that my position is one of privilege and that I am not affected by the ramifications of the themes discussed. My main intention is to amplify Black feminist voices. background for the analysis, including fundamental theoretical terms and previous research on (anti) racist discourse. Next, the methodology for the analysis will be discussed, followed by the analysis and discussion of results that emerged from the video data. The final section concludes the article and offers avenues for future research.

For the purpose of providing the relevant background, it is important to discuss key terms such as (anti) racism and Black Feminism. Racism in the current paper is defined as a system of social domination based on race/ethnicity (Bonilla-Silva 1997; Van Dijk 2005). That is, racism is not merely a matter of individual prejudicial attitudes or beliefs but is part of the structure of society (Bonilla-Silva 1997). There has been a large body of scholarship dedicated to discourse and racism, particularly in Europe, the U.S., and Latin America (see, for example, BonillaSilva and Forman, 2000; Wodak and Van Dijk, 2000; Casaravilla, 2003; Van Dijk, 2003, 2009; Courtis et al., 2009; Courtis, 2012; Limerick, 2020). Several discursive strategies have been identified, such as positive-self presentation, negative-other presentation, the denial of racism, and apparent sympathy, among many others, and primary findings generally indicate subtle forms of racism (but see, e.g., Moore \& Bell 2019 on overt racist speech on U.S. campuses) as seen and heard through the denial of racial discrimination and the negative presentation of minorities and 
immigrants in the press, media, political discourse, etc. (Van Dijk, 2003). Anti-racist discourse, however, has received less attention. Following Van Dijk (2015:77), anti-racism is defined in the present analysis as a social system that "consists of a subsystem of antiracist social practices (protests, etc.) based on a subsystem of anti-racist social cognition (anti-racist ideology and anti-racist attitudes)". He further highlights that anti-racist discourse is one of the main anti-racist practices and the way in which anti-racist cognitions are acquired and reproduced (Van Dijk 2015: 77). Van Dijk (2015, 2020) has extensively analysed anti-racist discourse in Brazil, specifically debates concerning anti-racist policies in the Brazilian government such as affirmative action and the Statute of Racial Equality, and outlines several discourse structures and strategies. For example, Van Dijk (2015:80) highlights the importance of selfpresentation in debates by Afro-Brazilian anti-racists, stating that initial discourse regarding different social and ethnic identities (e.g. Black, militant, university rector, etc.) serves to legitimise their participation in the debate and to give them credibility.

Additionally, their participation in specific organisations (e.g. the government, a worker's movement) also serves this function. Notably, such self-presentations also "guide the way the hearers will understand and interpret the discourses of the speakers" (Van Dijk 2015:80). Other discourse structures highlighted by Van Dijk (2015) are the description of the group (e.g. use of the pronoun nós 'us' to indicate membership in the Afro-Brazilian community), 'Us vs. Them' polarisation between racists and anti-racists (and blacks vs whites), arguments that carry implications and presuppositions, such as implying that opponents of the Statute deny racism in Brazil, or simply presupposing that Brazil currently suffers from racial inequality (e.g. we are fighting for equality), as well as the use of metaphors, statistics or the 'numbers game', and international comparisons, among other semantic structures. ${ }^{2}$

Black Feminism was established in the 1970s and has been discussed by several intellectuals (e.g. Lorde 1984, Hooks 1984, Smith 1995, Collins 2000, Simien 2004). According to Simien (2004), Black Feminism is the belief that "African American women are status deprived because they face discrimination on the basis of race and gender. Having to bear the burdens of prejudice that challenge people of color, in addition to the various forms of subjugation that hinder women, African American women are disadvantaged doubly in the social, economic, and political structure of the United States" (Simien 2004:83). Some of the primary

\footnotetext{
${ }^{2}$ For a more detailed analysis of anti-racist discourse in Brazil, see Van Dijk (2020). See also Limerick (2020) for an analysis of anti-racist (and more generally, anti-populist) discourse in the U.S., specifically surrounding the Central Park Five case.
}

themes treated in previous Black Feminism scholarship have been (a) Intersectionality (Crenshaw 1991; Collins 2004), (b) Gender inequality within the black community (Collins 2000; Hooks 1984), and (c) Collective membership or solidarity among Black women concerning political activism (Wilcox, 1990). The term intersectionality was coined by Kimberlé Crenshaw (1991), and it denotes the idea that we must consider all types of oppressions simultaneously (rather than just one independently) (Collins, 2004). For example, we must engage with race, class, and gender when addressing oppression systems and marginalised people (Crenshaw, 1991). As GolashBoza (2016) points out, for instance, racial ideologies are not only racialised but are also classed and gendered.

The current study is informed by previous research in (critical) discourse analysis as well as pragmatics and will address discourse structures such as lexical choice, presupposition (Van Dijk, 2015, 2020), and person-reference and identity (De Fina 1995, 2003; Limerick, 2017) as manifested in discourse. This latter issue will particularly examine the notions of solidarity or group membership and identification (Martín-Rojo, 1997) and personalisation or personal participation in a topic (De Fina, 1995) through the use of pronominal choice. In addition, we explore pragmatic functions, specifically the conducive use of tag questions (Moore \& Podesva, 2009) by speakers in Black Feminist discourse. The following research questions guided the analysis:

a) What recurring themes emerge in Black feminist discourse?

b) What discursive strategies and discourse structures are used in the anti-racist discourse of and about Black women?

\section{Method}

The data for the present investigation come from four YouTube videos of Black Feminist discourse that were yielded by the search term "Black Feminism". The only restriction was in relation to the timeframe and interest in relatively recent discourse; thus, out of fifteen relevant videos identified from the search term, we selected four videos that were uploaded within the past five years (2016-2019). Furthermore, the videos displaying primarily academic discourse were excluded due to the fact that there already exists extensive analyses of Black Feminist theory and academic discourse, as shown by the academic literature referenced in the previous section. Two of the videos feature informal conference talks/panels, whose titles and speaker names are below in (a) and (b). The other two videos consisted of news programs, seen in (c) and (d). 
a) \#SayHerName: Stories and Strategies to End Mass Criminalization" (Charlene Carruthers) (University of New England 2016)

b) "Black feminism \& the Movement for Black Lives" (Barbara Smith, Reina Gossett, Charlene Carruthers) (National LGBTQ Task Force 2016)

c) PBS News Hour: "An 'unapologetic' black feminist on accelerating the pace of change" (PBS News Hour 2019)

d) France 24 News: "The 51\% Percent - The Rise of Black Feminism” (France 24 English 2017)

In order to explore common themes across the videos, the current study involved the qualitative method of thematic analysis (Braun \& Clarke 2006), which enables one to create themes based on recurring discourse topics systematically. Following Khan et al. (2019), the primary concern in the present study was not to obtain a large sample size but rather to obtain a selective sample that yields analytically useful interpretations (see also Baker 2006 for similar methodological perspectives).

\section{Findings}

\subsection{Call for Inclusion of Black Women}

One of the main themes observed across the four videos analysed was simply that of the call for the inclusion of Black women. The following excerpt from the video "Black feminism \& the Movement for Black Lives" by Barbara Smith illustrates an aspect of this theme, specifically the idea of making space for Black women to be more visible, active, and expressive:

(1) We just wanted to make a space for ourselves in this world... we saw that we had to talk about all the kinds of oppressions that affected our lives, not just one...and we definitely had a critique and were reacting to the single-issued politics of the white women's movement, the bourgeois white women's movement...um we were also critical of ah the black ah movement by that time it was uh Black nationalism and Black power, not civil rights, ah of course inflected by but it had moved onto another stage and those politics were generally male-defined and, we also were critical of the single-issued focus of the new gay liberation movement, so we were just trying, as I said, to carve out a place for ourselves but we also understood that if we were successful and if we were able to do that then we would have carved out a space for every other kind of individual, every other kind..." [National LGBTQ Task Force 2016, 04:59]

In terms of discourse structures, we see the use of a presupposition with the phrases 'wanted to make a space' and 'trying [...] to carve out a place', the presupposition being that is that there was/is not a space for Black women. Additionally, the first-person plural pronouns 'we' and 'ourselves' are used, indicating that the speaker is included in this group and sees herself in solidarity with other Black feminists (Martín-Rojo, 1997; De Fina, 2003). The final part of (1) shows a proposition that constitutes a sub-theme in the data, namely that if Black women can be free/included, then everyone can be free/included.

Moreover, a noteworthy discourse strategy seen here is the criticism of other movements, such as the feminist movement, the Black Power movement, and the gay liberation movement. Specifically, these movements are characterised with words/phrases that indicate their limitations, specifically regarding their inability to represent Black women. The speaker (Barbara Smith) uses the descriptors 'bourgeois white' 'male-defined, and 'single-issued' to highlight the classed, racialised, and gendered nature of such movements, which ultimately exclude Black women. In doing so, she legitimises and highlights the unique importance of the Black feminist movement.

Another aspect of the inclusion of Black women is seen in the following excerpt from Charlene Carruther's discourse, in which she uses the specific name of a Black woman to emphasise the need for inclusion:

(2) Rekia Boyd unfortunately and and and tragically, tragically, is one of many transgender and cisgender Black women who have been criminalised, incarcerated or killed under systems of state violence, one of way too many, just one of many, the list of names is long, right? and she is one of many[...] if we want to be serious about the work of Dr. King or we want to celebrate his dream of living in a better world, Rekia Boyd has to be included in what that dream is, right? The taking of her life has to be included in what that dream is, and as I said, the list of names is long, and their stories are, while they are painful, they also hold profound and essential notes of resistance [University of New England 2016, $16: 24]$

In this case, the speaker refers to Rekia Boyd, a transgender Black woman killed by police in Chicago. In reference to MLK and his dream, Charlene uses Rekia Boyd as a concrete illustration of what the inclusion of Black women should look like while also emphasising that Rekia Boyd is just one of many Black women that has suffered state violence and that the list of names is long. Charlene also draws attention to the stories of such women, highlighting that, despite being painful, the stories themselves comprise significant sources of resistance.

Moreover, her discursive strategy of using a tag question (right?) is noteworthy. The function of using this tag question in this context is not to confirm, question, or mitigate (as it is a rhetorical question), 
but rather to assert confidence in the previous proposition and to draw the listener's attention to it to persuade and encourage the audience to take a stance of alignment (Du Bois, 2007). This function is similar to what Moore and Podesva (2009) call conducive meaning in that the tag question "encourage[s] the hearer to agree with a proposition" and that the speaker may be "enlisting support for a contentious claim (Moore \& Podesva 2009:458-459).

From a broader perspective, Brittany Cooper appeals to identity in stating that it is difficult at times to be both Black and Feminist simultaneously, but that what will save us is taking on both of those identities, thus drawing the listener to consider the importance of the inclusion of blacks and feminists, more specifically Black women:

(3) I'm a Black Feminist, capital B capital F, I'm unapologetically Black, and I'm unapologetically a Feminist and look, depending on what circles you're in, it is hard to be both those things at the same time, but I think being both those things is the thing that will save us [PBS News Hour 2019, $0: 25]$

Because both blacks and feminists are often excluded and unrecognised, it is "hard to be both those things" in some circles. Brittany alludes to intersectionality here, drawing attention to both racialised and gendered marginalisation and identities. Additionally, a presupposition emerges from the lexical choice of save, namely that we are currently not safe and that issues on the ground require attention. Black feminism, then, according to Cooper, is a powerful force shaping and improving the future of humankind. Cooper also exhibits a high use of the first-person singular pronoun 'I' (e.g. I think), reflecting an evaluative stance (Biber \& Finegan, 1988; Du Bois, 2007).

Another illustration of the demand for the Inclusion of Black women theme is seen in a news report from France. The reporter, Annette Young, emphasises the view from Black women that White women are not recognising (hence not including) Black women's struggle in the feminist movement.

(4) ...they say that their struggle is not being recognised by white women. In fact, they are facing double discrimination on both grounds of colour and gender. [France 24 English 2017, 0:14]

This excerpt is from the news program "The 51\%", which appeared on France 24. The initial headline at the beginning of the clip read "Equality in Trump's America: The rise of Black Feminism". Discursively, "their struggle isn't being recognised" generates a presupposition that there, in fact, exists a struggle for Black women, and the lexical choice of "struggle" represents a common discourse strategy in anti-racist discourse, namely the use of metaphor (Van Dijk, 2020) Moreover, the phrase "double discrimination" highlights intersectionality and the simultaneous oppression of race and gender for Black women. Interestingly, while not a primary focus of his study, Van Dijk (2020) emphasises the intersectional discourse about Black women in Brazil and finds the exact phrase being used. This suggests that "double discrimination" is a common phrase used to refer to Black women in different discourse genres as well as national contexts and may be a general property of Black feminist discourse.

\subsection{Police Brutality and Unaccountability}

The second major theme that emerged from the video data was that of Police Brutality. To begin, I present an excerpt from Brittany Cooper in which she highlights the frequent killing of Blacks by police as well as the unaccountability of police:

(5) We keep on relitigating basically the 1860s in this country, we have racial animus the likes of which we have not seen in my lifetime, a resurgence of law enforcement engaging black folks that are often deadly and often with impunity [PBS News Hour 2019, 1:37]

Cooper's lexical choice of 'animus' to describe the racial situation in the U.S. also emphasises the hostility and spiteful attitudes toward Blacks. Additionally, the use of the lexical items 'relitigating' and 'resurgence', particularly the re-prefix, highlights that racism is cyclical and systemic. ${ }^{3}$

Moreover, one subtheme of police and police brutality was the notion of safety and that Black women don't feel safe around police:

(6) The police don't keep us safe, and I should say all of us are safe; the police keep some people safe, right? If you're, you're more likely to be safe if you're a property owner, if you're white, if you're able-bodied, if you're cisgender, if you are a citizen, if you are Christian, all these, these certain things that hold privileges and power in society right? But they surely don't keep me safe I don't feel safe at all uh with the police and I don't feel safe with my- I don't feel that my family is safe with the police or my friends as well [University of New England 2016, 29:08]

In the above excerpt, one again identifies an evaluative stance by the speaker in using first-person singular pronouns 'I' and 'me' upon expressing that the police do not keep her safe and that she does not feel safe with the police. Additionally, she demonstrates a high level of involvement by conveying an individualised and personalised experience (...do not keep me safe; I don't feel safe) (De Fina 1995; 2003). At the same time, however, the use of the first-person plural $u s$ at the beginning of the excerpt reflects her

\footnotetext{
${ }^{3}$ Many thanks to an anonymous reviewer for pointing out this particular lexical and morphological function.
} 
collective identity as part of a group of marginalised people, precisely one that is not kept safe by the police. Like Barbara Smith's discourse presented in Excerpt 1, Charlene is conveying solidarity with other Black women in particular and other minorities more generally (Martín-Rojo 1997). Such patterns of referential switching to either personalise or generalise experiences are common in discourse (De Fina 2003; Limerick 2017).

\subsection{Black Feminism Defined}

The third main theme that emerged from the dataset was Black Feminism Defined. This theme comprises any appeal to Black Feminism itself, in description or definition. In other words, what notions, expressions, and topics fall under the umbrella of Black Feminism as described in discourse about Black Feminism, primarily by Black women. For the first illustration, this excerpt appears after a question from the moderator of the panel who simply asks "What is Black Feminism?" A prominent sub-theme that appears is intersectionality, as exemplified in the excerpt below:

(7) I think the thing that I think about when I think about Black Feminism is this moment of, just heightened violence ah for Black women who are trans, um the highest documented homicides ever happened this past year and the year before was the highest before that...And so when I think about Black Feminism I think about, how we cannot um get rid of gender norms and transphobia and the gender binary without getting rid of everything else that co-constitutes it [...] we can't, we can't afford to take in this, what I think is like an assimilationist push that transphobia can happen without addressing anti-black racism, right? [National LGBTQ Task Force 2016, 7:18]

In this case, Reina Gossett gives her perspective on what she personally associates with Black Feminism, namely the intersection of race, gender, and sexuality and specifically Black trans women and the problem of transphobia and its associated violence. Speaking to anti-racism, in particular, Reina highlights that it is impossible to dismantle transphobia without also engaging with anti-black racism. In terms of discursive strategies, we again see referential switching (from 'I' to 'we'), in which she begins with a more personalised view ("I think") and shifts to a collective viewpoint (we) in emphasising the plethora of issues that need to be addressed.

We see intersectionality echoed in propositions from Barbara Smith such as "we saw that we had to talk about all the kinds of oppressions that affected our lives, not just one..." [National LGBTQ Task Force 2016, 5:01]. In this context, Barbara specified that many people in the Black Feminist movement's beginnings, in addition to being Black Women, also identified as lesbians, working-class, and poor. Hence, she draws attention to the necessity of addressing not just one type of oppression, but the intersection of many simultaneously.

A second subtheme for Black Feminism Defined is that of Full Dignity (valuing and respecting someone for their own sake), represented across all four videos of the dataset, and illustrated explicitly with the discourse of Charlene Carruthers below:

(8) Charlene: I think Black Feminism requires us to expand, how we think of womanhood outside of binaries, and all that good stuff all that language that people in this room know, but essentially this idea that we should all be able to live within our full dignity, and I believe that, there are so many issues that are Black Feminist issues, the occupation of Palestine is a Black Feminist issue, right? because, because what is happening, what is happening due to the Israeli occupation, they, there have been streams, scores of reports of the sterilisation of women from East Africa, that is a Black Feminist issue, right? [National LGBTQ Task Force 2016, 09:56]

A core idea of Black Feminism, as reflected in the videos, is the freedom to live within one's full dignity, regardless of one's identity, which in the case above specifically points to gender identity as well as less visible groups such as East African women. Again, we see the use of the tag question 'right?' with the intention of conducing (Moore \& Podesva, 2009) the audience to align or agree with the preceding propositions.

\section{Discussion}

\subsection{What Recurring Themes Emerge in Black Feminist Discourse?}

The primary themes that emerged from the video data were the following: The inclusion of Black women, Police brutality and unaccountability, and Black Feminism defined. Numerous sub-themes were also observed, such as Making space in the world, Reference to specific Black women, Safety, Intersectionality, and Full Dignity.

In a much broader sense, the discourse analysed made a connection to (anti) racism more generally (and not only to Black feminism or Black women in particular). It reinforces the importance of understanding racism as systemic rather than on the level of individual prejudice (Bonilla-Silva 1997; Van Dijk 2005; among many others). This was seen, for instance, through the major theme of systemic police brutality observed in the videos. Furthermore, the current data reflects and lends support to Van Dijk's (2015) notion of anti-racism. In the context of the videos examined, we observed anti-racist social practices through conference talks and news reports concerning Black feminism in particular and antiracism more generally. These social practices were 
based on anti-racist social cognitions (ideologies and attitudes) on the part of the speakers.

\subsection{What Discursive Strategies and Discourse Structures Are Used in the Anti-Racist Discourse of and About Black Women?}

Numerous discourse structures/discursive strategies were analysed in the videos, namely lexical choice, presupposition, pronominal choice, and the use of conducive tag questions. Examples of lexical choice included "save" and "animus", denoting the seriousness of racism for Black women and the need to be rescued from it. Other lexical choices such as "single-issued" and "male-defined" denoted criticisms of other social movements. Regarding presuppositions, one of the recurring ones was that there was/is not a space for Black Women in the world. In terms of pronominal choice, first-person plural pronouns were used to convey solidarity with Black Feminists (Martín-Rojo 1997; De Fina 2003). First-person singular pronouns conveyed an evaluative stance as well as an individualised and personalised experience (e.g. do not keep me safe; I don't feel safe) (De Fina 1995; 2003). Finally, the use of the tag question "right"? Was used for conducive meaning (Moore \& Podesva 2009) or to persuade the listeners to align or agree with the previous proposition made by the speaker.

Importantly, many of these anti-racist discursive strategies and themes counter and show resistance to the narratives heard in racist discourse. For example, as stated in the Introduction, the denial of racism is a major strategy noted in studies of discursive racism (e.g. Bonilla-Silva \& Forman 2000; Van Dijk 2003; Zavala \& Zariquiey 2009). The current data show overt opposition to this idea by highlighting the existence and reality of systemic racism in the U.S. and beyond. Moreover, in contrast to the 'apparent' sympathy for marginalised people often seen in racist discourse (Van Dijk 1997), the Black Feminist discourse here reflects genuine sympathy and compassion for minorities (e.g. we would have carved out a space for every other kind of individual, every other kind; Rekia Boyd has to be included; etc).

As the first study (to the best of my knowledge) to examine Black Feminist language from a Critical Discourse Studies perspective, the current analysis begins to fill a gap in the field and to serve as a base for future work by establishing some key properties and structures of Black Feminist discourse.

\section{Conclusion}

This preliminary analysis revealed a number of themes that emerged in Black Feminist discourse as well as discursive strategies employed from a discourse analytic perspective. The findings contribute to the analysis of anti-racist discourse, an understudied topic in Critical Discourse Studies. This study serves to further our understanding of the linguistic manifestation of ideologies through discourse concerning anti-racism in general and Black Feminism in particular. Crucially, the discourse analysed in the videos reflects an essential notion concerning Black Feminism, that of intersectionality, through the discussion of double discrimination, transphobia against Black transgender women, and utterances such as "all kinds of oppressions [...] not just one". While some of the strategies, functions, and themes examined apply to many types of discourses more broadly, other properties reflect Black Feminist discourse in particular, such as reference to specific Black women, intersectionality, solidarity with other Black feminists, the notion of double discrimination, criticism of other movements, and the idea that if Black women can be free, everyone can be free. Such properties are consistent with the key topics of Black Feminist scholarship, which were discussed in the Introduction.

There are many avenues for future research and opportunities to expand upon the current study. First, an analysis of a larger number of videos would give a more representative view of Black Feminist discourse and how it ties to anti-racist discourse more generally. This would also potentially reveal additional themes and discursive strategies not discussed in the current paper. Additionally, it would be beneficial to examine the responses and reactions to the videos by analysing the YouTube text comments that appear with each video. In this way, we could uncover how the content is perceived and what types of attitudes emerge as a result of listening to Black Feminist discourse. Finally, future work should consider the potential pedagogical applications to anti-racist discourse analysis to amplify marginalised voices and educate others for social change. It is our hope that, through watching and reflecting upon the media examined in this paper and others with similar discourse themes and strategies, anti-racist and Black Feminist cognitions can be further acquired and reproduced (Van Dijk 2015).

\section{References}

Baker, P. (2006) Using Corpora in Discourse Analysis. London: Continuum.

Biber, D and Finegan, E. (1988). Adverbial Stance Types in English. Discourse Processes, 11(1) $1-34$.

Bonilla-Silva, E. (1997). Rethinking racism: Toward a structural interpretation. American Sociological Review, 62(3), 465-80.

Bonilla-Silva, E., \& Forman, T. A. (2000). "I'm not a racist but ...": mapping White college students' racial ideology in the USA. Discourse \& Society, 11(1), 50-85.

Casaravilla, D. (2003). Crisis social, discurso y xenofobia. In Programa Todas, Buenos Aires. Ciudad con migrantes (pp. 15-28). Buenos 
Aires: Dirección General de la Mujer, Gobierno de la Ciudad de Buenos Aires.

Courtis, C., Inés Pacecca, M., Lenton, D., Belvedere, C., Caggiano, S., Casaravilla, D., \& Halpern, G. (2009). Racism and discourse: A portrait of the Argentine situation. In T. A.Van Dijk, (Ed.), Racism and Discourse in Latin America (pp. 13-55). Lanham: Lexington Books.

Courtis, C. (2012). Discriminación étnico-racial: discursos públicos y experiencias cotidianas: Un estudio centrado en la colectividad coreana. Buenos Aires: Editores del Puerto.

De Fina, A. (1995). Pronominal choice, identity, and solidarity in political discourse. Text, 15(3), 379-410.

De Fina, A. (2003). Identity in narrative: A study of immigrant discourse. Philadelphia: John Benjamins.

Du Bois, J. W. (2007). The stance triangle. In Stancetaking in Discourse: Subjectivity, Evaluation, Interaction, Robert Englebretson (ed.), 139-182. Amsterdam: Benjamins.

Braun, V., \& Clarke, V. (2006). Using thematic analysis in psychology. Qualitative research in psychology, 3(2), 77-101.

Collins, Patricia Hill. (2000). Black Feminist Thought, 2nd ed. New York: Routledge.

Collins, P. H. (2004). Black Sexual Politics: African Americans, gender, and the new racism. Routledge: New York.

Cooper, B. (2018). Eloquent Rage: A Black Feminist Discovers Her Superpower. New York: St. Martin's Press.

Crenshaw, K. (1991). Mapping the Margins: Intersectionality, identity politics, and violence against women of color. Stanford Law Review, 43 (6), 1241-1299.

France 24 English (2017). The 51\% Percent - The Rise of Black Feminism, YouTube, uploaded April 3 , 2017 , https://www.youtube.com/watch?v=eZP0tU37 $\underline{\mathrm{n} 5 \mathrm{~A}}$

Golash-Boza, T. (2016). A critical and comprehensive sociological theory of race and racism. Sociology of Race and Ethnicity, 2(2), 129-141.

Hooks, B. (1984). Feminist theory: From margin to center Boston. MA: SAGE Publications.

Khan, M. H. et al. (2019). Muslims' Representation in Donald Trump's Anti-Muslim-Islam Statement: A Critical Discourse Analysis. Religions 10.115, 1-16.

Limerick, P. P. (2017). Identity in discourse: Personreference among Mexicans in the Southeastern
U.S. Lengua y migración / Language and Migration, 9(1), 85-112.

Limerick, P. P. (2020). Populist and Anti-Populist Discourse Concerning African-Americans. A Critical Discourse Analysis of the Central Park Five Case. Iperstoria, (15).171-187.

Lorde, A. (1984). Sister Outsider. Freedom, CA: The Crossing Press.

Martín-Rojo, L. (1997). The politics of gender: Agency and self-reference in women's discourse. In Political Linguistics, Jan Blommaert and Chris Bulcaen (eds.), 231-254. Amsterdam: John Benjamins.

Moore, W. L., \& Bell, J. M. (2019). The limits of community: deconstructing the White framing of racist speech in universities. American behavioral scientist, 63(13), 1760-1775.

Moore, E., \& Podesva, R. (2009). Style, indexicality, and the social meaning of tag questions. Language in Society, 38(4), 447-485.

National LGBTQ Task Force. (2016). Black Feminism \& the Movement for Black Lives: Barbara Smith, Reina Gossett, Charlene Carruthers, YouTube, uploaded January 23, 2016,

https://www.youtube.com/watch?v=eV3nnFhe QRo

PBS News Hour. (2019). An 'unapologetic' black feminist on accelerating the pace of change, YouTube, uploaded February 25, 2019, https://www.youtube.com/watch?v=s9r0nafcEr $\mathrm{U} \& \mathrm{t}=39 \mathrm{~s}$

Simien, E. M. (2004). Black feminist theory: charting a course for black women's studies in political science. Women \& Politics, 26(2), 81-93.

Smith, B. (1995). Some Home Truths about the Contemporary Feminists Movement. In Words of Fire: An Anthology of African-American Feminist Thought, ed. Beverly Guy-Sheftall. New York: The New Press.

University of New England. (2016). UNE: \#SayHerName: Stories and Strategies to End Mass Criminalization, YouTube, uploaded February 1, 2016, https://www.youtube.com/watch?v=QOiA9wvuOU

Van Dijk, T. A. (1997). Political Discourse and Racism: Describing Others in Western Parliaments. In S. H. Riggins (Ed.), The Language and Politics of Exclusion: Others in Discourse (pp. 31-64). Thousand Oaks, CA: Sage. 
Van Dijk, T. A. (2003). Dominación étnica y racismo discursivo en España y América Latina. Barcelona: Gedisa.

Van Dijk, T. A. (2005). Racism and Discourse in Spain and Latin America. Amsterdam: John Benjamins.

Van Dijk, T. A. (Ed.) (2009). Racism and Discourse in Latin America. Lanham: Lexington Books.

Van Dijk, T. A. (2015). Critical Discourse Studies: A Sociocognitive Approach. In Wodak \& Meyer (eds.), Methods of critical discourse studies (3rd edition). pp. 63-85. London: Sage.

Van Dijk, T. A. (2020). Anti-racist discourse in Brazil: From abolition to affirmative action. London: Lexington Books.

Wilcox, C. (1990). Black Women and Feminism. Women \& Politics, 10 (3), 65-84.

Wodak, R., \& Meyer, M. (2009). Critical discourse analysis: History, agenda, theory, and methodology. In Methods of critical discourse analysis (2nd ed.). London: Sage, 1-33.

Wodak, R., \& Van Dijk, T. A. (Eds.) (2000). Racism at the Top: Parliamentary Discourses on Ethnic Issues in Six European Countries. Klagenfurt: Drava Verlag.

Zavala, V., \& Zariquiey, R. (2009). "I segregate you because your lack of education offends me": An approach to racist discourse in contemporary Peru. In T. A. Van Dijk (Ed.), Racism and Discourse in Latin America (pp. 259-289). Lanham: Lexington Books. 